\title{
Cycloheximide inhibition of ovulation, prostaglandin biosynthesis and steroidogenesis in rabbit ovarian follicles
}

\author{
L. L. Espey \\ Department of Biology, Trinity University, San Antonio, Texas 78284, U.S.A.
}

\begin{abstract}
Summary. Cycloheximide ( $5 \mathrm{mg} / \mathrm{kg}$, i.v.) significantly inhibited ovulation in the rabbit when it was administered as early as $20 \mathrm{~h}$ before the ovulation process was initiated by $\mathrm{hCG}$, and as late as $1 \mathrm{~h}$ after hCG. The ovulation rate was significantly reduced, but follicular biosynthesis of prostaglandins $E$ and $F$ was only partly inhibited. The biosynthesis of progesterone and oestradiol in follicles during the early stages of the ovulation process was also inhibited. Cycloheximide may therefore inhibit ovulation by a mechanism which is different from the action of indomethacin, and this mechanism may involve the suppression of ovarian steroidogenesis.
\end{abstract}

\section{Introduction}

Cycloheximide is an agricultural fungicide which is obtained from the soil bacterium, Streptomyces griseus. Two decades go, Pool \& Lipner (1966) reported that cycloheximide can inhibit ovulation in the rabbit when it is injected directly into mature ovarian follicles. These investigators noted that cycloheximide was most effective in preventing ovulation when it was injected into the follicles no later than $2 \mathrm{~h}$ after the animals received human chorionic gonadotropin (hCG), i.e. $\sim 8 \mathrm{~h}$ before the expected time of ovulation.

Cycloheximide can also inhibit ovulation when it is administered intraperitoneally (i.p.) into rabbits at $1 \mathrm{~h}$ after the animals received hCG (Espey et al., 1982). However, the optimum time to give this agent was not established. The present study is a more extensive analysis of the effect of cycloheximide on ovulation.

\section{Materials and Methods}

Animals. Rabbits were selected as the experimental animals because they conveniently ovulate at $10 \pm 1 \mathrm{~h}$ after receiving hCG. Each of the 140 New Zealand White rabbits used in the study was selected on the basis of whether its vaginal orifice was red (rather than whitish or deep purple), because this colour is more indicative of normal oestrus. Animals that had ovaries with adhesions, tumours, or immature follicles at autopsy were excluded from the data tabulations.

Ovulation induction. Ovulation was induced by hCG (CG-5, Sigma Chemical Company, St Louis, $\mathrm{MO}$ ) at a dose of $50 \mathrm{i} . \mathrm{u} . / \mathrm{kg}$, i.v. The animals were anaesthetized with pentobarbitone sodium and a laparotomy was performed to obtain ovaries for experimental analysis. In the tests to determine the optimum time to administer cycloheximide to inhibit ovulation, both ovaries were removed between 10 and $15 \mathrm{~h}$ after the expected time of ovulation (i.e. $20-25 \mathrm{~h}$ after hCG) and examined under a dissecting microscope to determine the number of ruptured follicles. In the experiments on prostaglandins (PGs), all ovaries were taken at the expected time of ovulation (i.e. at $10 \mathrm{~h}$ after hCG). In the experiments on steroids, the ovaries were taken at the designated times. 
Prostaglandin radioimmunoassay. Immediately after excision of the ovaries, 3 mature follicles were dissected from the stromal tissue of each pair of ovaries and transferred to a preweighed $2 \cdot 0 \mathrm{ml}$ glass homogenizer tube (S73, Tri-R Instruments, Inc., Rockville Center, NY), which contained $1.0 \mathrm{ml} 0.1 \mathrm{M}$-acetate buffer ( $\mathrm{pH} \mathrm{4.5)}$ ) and $20 \mu \mathrm{g}$ indomethacin to prevent any further synthesis of PGs. (The indomethacin was dissolved in DMSO at a concentration of $2.0 \mu \mathrm{g} / \mathrm{ml}$ and added by microburette to the acetate buffer.). The homogenizer tube was then reweighed to calculate the weight of the 3 follicles. Next, the follicles were homogenized for $1 \mathrm{~min}$ with a glass pestle (S62, Tri-R) connected to a stirrer (S63, Tri-R) set at medium speed (5000 rev./min). The interval between excision of the ovaries and completion of the homogenization was approximately $10 \mathrm{~min}$. The homogenate was transferred to a polyethylene tube, capped and stored at $-30^{\circ} \mathrm{C}$ until a complete series of experimental samples could be assayed simultaneously for PG. (In no instance were the samples stored for longer than 3 weeks.) The RIAs were performed according to procedures described elsewhere (Harper et al., 1981). Although the antibodies were produced by innoculating rabbits with PGE-2 and PGF-2 $\alpha$, the results are expressed simply as PGE and PGF because the antibodies cross-react essentially $100 \%$ with PGE- 1 and PGF- $1 \alpha$, respectively. The intra- and interassay coefficients of variation were, respectively, $10.7 \%$ and $9.8 \%$ for PGF and $11.6 \%$ and $5.0 \%$ for PGE. The results are expressed as pg PG per $\mathrm{mg}$ follicle (wet weight).

Steroid radioimmunoassay. Follicles for the RIAs of oestradiol and progesterone were obtained in the same manner as for the PG assays, except that, in the steroid assays the follicles were homogenized in $0 \cdot 1 \mathrm{M}$-phosphate buffer ( $\mathrm{pH} \mathrm{7.6)}$. The RIAs were performed according to procedures described elsewhere (Siler-Kodhr et al., 1984). For oestradiol, assay sensitivity was $10 \mathrm{pg} / \mathrm{ml}$, cross-reaction with oestrone was $0.08 \%$, and the intra- and interassay coefficients of variation were $8.4 \%$ and $12 \%$, respectively. For progesterone, assay sensitivity was $36 \mathrm{pg} / \mathrm{ml}$, the only crossreactions were for $5 \alpha$ - and $\beta$-pregnanedione (15\% and $20 \%$, respectively), and the intra- and interassay coefficients of variation were $3.7 \%$ and $14.3 \%$, respectively.

Statistical analysis. All data are presented as the mean \pm s.e.m. The significance of the differences between experimental groups in the temporal and PG studies were determined by Student's $t$ tèst. Significant differences in the steroid hormone data were determined by Wilcoxon's test for relatively small numbers of samples. In all cases, the level of significance was taken as $P \leqslant 0.05$.

\section{Results}

\section{Optimum time to administer cycloheximide}

In control animals, $75.8 \pm 4.4 \%$ of the mature follicles ovulated in response to hCG stimulation (Fig. 1). When cycloheximide was given any time between $20 \mathrm{~h}$ before and $1 \mathrm{~h}$ after $\mathrm{hCG}$, the ovulation rate was significantly reduced $(P<0.01)$.

\section{Effect of cycloheximide on $P G$ production in ovulatory follicles}

In normal oestrous rabbits, the average PGE concentration in unstimulated mature follicles was $113 \cdot 3 \pm 20 \cdot 1 \mathrm{pg} / \mathrm{mg}$ follicle. At $10 \mathrm{~h}$ after $\mathrm{hCG}$ (i.e. at the expected time of ovulation) the control level of PGE was $685.4 \pm 49.8 \mathrm{pg} / \mathrm{mg}$ follicle. In comparison, when $5 \mathrm{mg}$ cycloheximide $/ \mathrm{kg}$ were administered at $10 \mathrm{~h}$ before hCG, the PGE level at the expected time of ovulation was $325.7 \pm 31.7 \mathrm{pg} / \mathrm{mg}$ follicle $(P<0.001)$. At the same time, the ovulation rate decreased $(P<0.0001)$ from a control level of $73.6 \pm 4.5 \%$ to $1.2 \pm 1.2 \%$. In contrast, when the same dose of cycloheximide was administered at $1 \mathrm{~h}$ after hCG, the PGE level of $596.9 \pm 51.6 \mathrm{pg} / \mathrm{mg}$ follicle at the expected time of ovulation was not significantly different $(P>0.20)$ from the control level, 


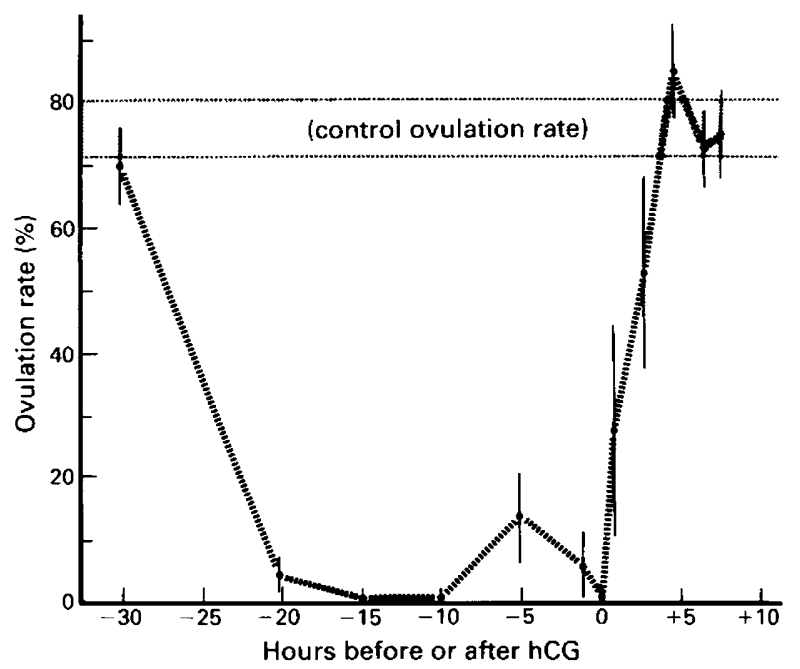

Fig. 1. Ovulation efficiency of rabbits after cycloheximide administration at times before and after hCG. Values are mean \pm s.e.m. for 10 control and 5 experimental animals.

although ovulation was still almost completely inhibited $(P<0.0001)$, with only $1.8 \pm 1.8 \%$ of the large follicles rupturing. When cycloheximide was given at $8 \mathrm{~h}$ after hCG, PGE was reduced to $361 \cdot 2 \pm 33.1 \mathrm{pg} / \mathrm{mg}$ follicle, which was approximately the same level $(P>0.40)$ as when this agent was administered at $10 \mathrm{~h}$ before hCG but ovulation proceeded at a rate of $58.5 \pm 8 \cdot 5 \%$, which was not significantly different $(P>0 \cdot 10)$ from the rate in control animals.

The PGF levels were parallel to those of PGE, with the amounts at $10 \mathrm{~h}$ before, $1 \mathrm{~h}$ after, and $8 \mathrm{~h}$ after hCG being $88 \cdot 4 \pm 8 \cdot 7,204 \cdot 4 \pm 11 \cdot 9$, and $138 \cdot 8 \pm 11 \cdot 3 \mathrm{pg} / \mathrm{mg}$ follicle, respectively.

\section{Effect of cycloheximide on steroid production in ovulatory follicles}

The normal amount of progesterone in mature follicles of animals that had not been stimulated by an ovulatory dose of hCG was $2.92 \pm 0.49 \mathrm{ng} / \mathrm{mg}$ follicle (wet weight). Within $2 \mathrm{~h}$ after the ovulatory process had been stimulated by hCG, the progesterone level had increased $(P \leqslant 0 \cdot 012)$ to $9.54 \pm 2.83 \mathrm{ng} / \mathrm{mg}$ follicle. However, when $5 \mathrm{mg}$ cycloheximide $/ \mathrm{kg}$ were given $10 \mathrm{~h}$ before hCG, the progesterone level of $5 \cdot 36 \pm 2 \cdot 27 \mathrm{ng} / \mathrm{mg}$ for follicles taken at $2 \mathrm{~h}$ after hCG was significantly less $(P \leqslant 0.019)$ than in control follicles taken $2 \mathrm{~h}$ after hCG. Cycloheximide therefore inhibited progesterone synthesis.

The normal amount of oestradiol in mature follicles of animals which had not been stimulated by hCG was $11.18 \pm 1.99 \mathrm{pg} / \mathrm{mg}$ follicle. Within $2 \mathrm{~h}$ after the follicles had been stimulated by hCG, the oestradiol level had increased $(P \leqslant 0.002)$ to $21.80 \pm 2.44 \mathrm{pg} / \mathrm{mg}$ follicle. However, after cycloheximide, the oestradiol level of $13.48 \pm 1 \cdot 13 \mathrm{pg} / \mathrm{mg}$ follicle was significantly less $(P \leqslant 0.002)$ than in the control follicles taken at $2 \mathrm{~h}$ after hCG. Therefore, cycloheximide also inhibited oestradiol biosynthesis during the early stages of ovulation.

\section{Discussion}

This study shows that cycloheximide can inhibit ovulation. Like colchicine (Espey, 1983), cycloheximide is most effective when it is given before the ovulatory process has been initiated by hCG. This optimum time is earlier than that for indomethacin, a nonsteroidal anti-inflammatory 
drug which optimally inhibits rabbit ovulation when it is administered at $7 \mathrm{~h}$ after hCG (Espey, 1982).

Ovarian PG biosynthesis is reportedly essential for ovulation (Wallach et al., 1975; Armstrong, 1981), and indomethacin is well-known for its ability to inhibit PG synthesis (Espey, 1980). Cycloheximide is also known to inhibit PG biosynthesis in fibroblasts (Pong et al., 1977), macrophages (Bonney et al., 1980), granuloma tissue (Ohuchi et al., 1980), and, now, in ovulatory follicles. However, its action appears to be substantially weaker than that of indomethacin, which can virtually obliterate PG production by rabbit follicles within only $5 \mathrm{~min}$ (Espey et al., 1986).

Cycloheximide and indomethacin act at different steps along the anabolic pathway for PG biosynthesis. Cycloheximide interferes with arachidonic acid release-a step that may require protein synthesis for expression of phospholipase activity (Pong et al., 1977). However, indomethacin inhibits cyclo-oxygenase, the enzyme which converts arachidonic acid into the endoperoxides that produce PGs and their derivatives (Espey, 1980). Therefore, since the release of arachidonic acid from phospholipids and triglycerides must precede the conversion of this acid into PGs, it is reasonable to expect cycloheximide to be more effective at an earlier stage of the ovulatory process, while indomethacin is more effective at a later stage.

Cycloheximide could also inhibit ovulation by its suppression of follicular progesterone and oestradiol formation since there are reports that ovarian steroidogenesis is essential for ovulation (Lipner \& Greep, 1971; Rondell, 1974). Progesterone, in particular, may be important (Snyder et al., 1984; Lang et al., 1984). This steroid increases in rabbit follicles during the first hours of the ovulatory process (Bahr, 1978) which might explain why it is necessary to administer cycloheximide by $1 \mathrm{~h}$ after $\mathrm{hCG}$.

Cycloheximide can also reduce the production of plasminogen activator by fibroblasts (Crutchley et al., 1982) and of collagenase by Kupffer cells (Bhatnagar et al., 1982). Since both of these serine proteases have been implicated in the ovulatory process (Espey, 1980), their inhibition by cycloheximide could also account for the anti-ovulatory action of this agent. However, follicular proteolysis is one of the final events of ovulation, and therefore it seems more likely that cycloheximide would exert its effect by interfering with ovarian steroidogenesis and/or PG production.

I thank Catherine Norris and Elizabeth Hemmick for the RIAs, conducted at the Center for Research in Reproductive Biology, Department of Obstetrics and Gynecology, The University of Texas Health Science Center at San Antonio. This work was supported in part by NIH grant HD-21649 to Trinity University and NIH grant P30-HD-10202 to the Center for Research in Reproductive Biology, Department of Obstetrics and Gynecology, The University of Texas Health Science Center at San Antonio.

\section{References}

Armstrong, D.T. (1981) Prostaglandins and follicular functions. J. Reprod. Fert. 62, 283-291.

Bahr, J.M. (1978) Simultaneous measurement of steroids in follicular fluid and ovarian venous blood in the rabbit. Biol. Reprod. 18, 193-197.

Bhatnager, R., Shade, U., Rietschel, E. T. \& Decker, K. (1982) Involvement of prostaglandin $\mathrm{E}$ and adenosine $3^{\prime}, 5^{\prime}$-monophosphate in lipopolysaccharidestimulated collagenase release by rat Kupffer cells. Eur. J. Biochem. 125, 125-130.

Bonney, R.J., Wightman, P.D., Dahlgren, M.E., Davies, P., Kuehl, F.A., Jr. \& Humes, J.L. (1980) Effect of RNA and protein synthesis inhibitors on the release of inflammatory mediators by macrophages responding to phorbol myristate acetate. Biochim. Biophys. Acta $663,410-421$.

Crutchley, D.J., Conanan, L.B. \& Maynard, J.R. (1982) Stimulation of fibrinolytic activity in human skin fibroblasts by prostaglandins $\mathrm{E}_{1}, \mathrm{E}_{2}$ and $\mathrm{I}_{2} . J$. Pharm. exp. Therap. 222, 544-549.

Espey, L.L. (1980) Ovulation as an inflammatory reaction-a hypothesis. Biol. Reprod. 22, 73-106.

Espey, L.L. (1982) Optimum time for administration of indomethacin to inhibit ovulation in the rabbit. Prostaglandins 23, 329-335.

Espey, L.L. (1983) Inhibition of ovulation in the rabbit 
by the antimitotic agent, colchicine. Fert. Steril. $\mathbf{4 0}$, 525-529.

Espey, L.L., Stein, V.I. \& Dumitrescu, J. (1982) Survey of antiinflammatory agents and related drugs as inhibitors of ovulation in the rabbit. Fert. Steril. 38, 238-247.

Espey, L.L., Norris, C. \& Saphire, D. (1986) Effect of time and dose of indomethacin on follicular prostaglandins and ovulation in the rabbit. Endocrinology 119, 746-754.

Harper, M.J.K., Norris, C.J., Friedrichs, W.E. \& Moreno, A. (1981) Poly I:C accelerates ovum transport in the rabbit by a prostaglandin-mediated mechanism. J. Reprod. Fert. 63, 81-89.

Lang, G.F., Walton, J.S. \& Etches, R.J. (1984) The effect of aminoglutethimide on steroid secretion, ovulation, and luteinizing hormone release in the hen. Poult. Sci. 63, 1861-1867.

Lipner, H. \& Greep, R.O. (1971) Inhibition of steroidogenesis at various sites in the biosynthetic pathway in relation to induced ovulation. Endocrinology 88, 602-607.

Ohuchi, K., Sato, H., Kombayashi, T., Tsurufuji, S., Satoh, H. \& Levine, L. (1980) Prostaglandin production by minced carrageenin in granuloma tissue of rats and its inhibition by dexamethasone and cycloheximide. Prostaglandins Med. 5, 267-274.

Pong, S., Hong, S.L. \& Levine, L. (1977) Prostaglandin production by methylcholanthrene-transformed mouse BALB/3T3. J. biol. Chem. 252, 1408-1413.

Pool, W.R. \& Lipner, H. (1966) Inhibition of ovulation by antibiotics. Endocrinology 79, 858-864.

Rondell, P. (1974) Role of steroid synthesis in the process of ovulation. Biol. Reprod. 10, 199-215.

Siler-Kodhr, T., Keuhl, T.J. \& Vickery, B.H. (1984) Effects of a gonadotropin releasing hormone antagonist on hormonal levels in the pregnant baboon and on fetal outcome. Fert. Steril. 41, 448-453.

Snyder, B.W., Beecham, G.D. \& Schane, H.P. (1984) Inhibition of ovulation in rats with epostane, an inhibitor of $3 \beta$-hydroxysteroid dehydrogenase. Proc. Soc. exp., Biol. Med. 176, 238-242.

Wallach, E.E., Bronson, R., Hamada,Y., Wright, K.H. \& Stevens, V.C. (1975) Effectiveness of prostaglandin $\mathrm{F}_{2 a}$ in restoration of HMG-HCG induced ovulation in indomethacin-treated rhesus monkeys. Prostaglandins 10, 129-138.

Received 9 April 1986 